\title{
The Challenge of Providing Work-Integrated Learning for Law Students - the QUT Experience
}

\section{Melinda Shirley* \\ Iyla Davies** \\ Tina Cockburn**** \\ Tracey Carver ${ }^{* * * * *}$}

\section{SUMMARY:}

This paper explores the elements necessary for a university to create an academic model for a successful work-integrated learning experience in light of the current policy imperatives of the higher education sector in Australia. It identifies some of the practical issues encountered in attempting to implement those models and hypothesises on what an effective work-integrated learning experience for undergraduate law students should look like taking into account the available research on students' perceptions of engaging learning experiences. It culminates in the proposal of a Virtual Work Integrated Learning Project which is currently under design in the Faculty of Law at the Queensland University of Technology.

\section{INTRODUCTION}

Australian universities have been heeding the call to produce more capable graduates since the 1980 's. ${ }^{1}$ Much time and attention has been devoted to the incremental development of graduate attributes to

* $\quad$ BA LLB(Hons) Qld, LLM Bond, Assistant Dean, Learning and Teaching, Faculty of Law QUT

** LLB(Hons) QUT, LLM Qld, Assistant Dean, International and Community, Faculty of Law QUT

*** BCom LLB(Hons) Qld; LLM QUT, Grad Cert Ed (Higher Ed) QUT, SEDA Accredited Teacher in Higher Education, Senior Lecturer, Faculty of Law QUT

**** BBus (Accy) (Dist), LLB (Hons) QUT, LLM Cantab, Lecturer, Faculty of Law QUT

An earlier version of this paper was presented by Melinda Shirley, Iyla Davies and Tina Cockburn at ACEN (Australian Collaborative Education Network) Conference, Griffith University, Gold Coast, Australia, September 2006.

1 Legal Education and Professional Development - An Educational Continuum ABA Chicago 1992 (MacCrate Report); C McInnes, S Marginson $\mathcal{E}$ A Morris, Australian Law Schools After the 1987 Pearce Report, AGPS Canberra 1994. 
complement the acquisition of professional knowledge in every field. That shift in educational focus which centres on building students' skills and self awareness for future employment has also highlighted the desirability of work-integrated learning experiences to provide a context for skills development and an opportunity for students to prepare for the transition from university to professional practice.

Research into work-integrated learning experiences is a problematic exercise. Whilst large numbers of students around the world participate in work based education each year, there is great diversity in the nature of the programs offered. Such experiences range from highly structured university controlled placements for academic credit, to informal situations where students volunteer to be part of a workplace outside of the formal university semester.

The size of the student cohort in question, the nature of the professional experience sought and the geographical situation of the institution will all impact on a university's ability to create an enriching workplace experience for students. In addition, cyclical factors such as economic prosperity, political stability and environmental impact are also likely to affect the availability of collaborative education partners.

Compounding the definitional problems is the fact that there are many different titles for work-integrated learning experiences in the educational literature including: cooperative education, field placements, internships, experiential learning programs and externships, and these experiences are being offered and evaluated across fields as diverse as nursing, engineering, education and business.

Despite those challenges, this paper will attempt to identify the core elements of an effective workintegrated learning program in light of the current policy imperatives of the higher education sector in Australia. It will identify some of the practical issues encountered in attempting to implement those models and will hypothesise on what an effective work-integrated learning experience for undergraduate law students should look like taking account of the available research on students' perceptions of engaging learning experiences.

This paper will culminate in the proposal of a Virtual Work Integrated Learning Project which is currently under design in the Faculty of Law at the Queensland University of Technology as a possible solution to the experiential learning needs of undergraduate law students at that university.

\section{THE SEARCH FOR AN ACADEMIC MODEL}

\section{What is Work-integrated Learning?}

The United States National Commission for Cooperative Learning (USNCCL) defines cooperative education as:

.... a structured educational strategy integrating classroom studies with learning through productive work experiences in a field related to a student's academic or career goals. It provides progressive experience in integrating theory and practice. It is a partnership among students, educational institutions and employers, with specified responsibilities for each party.2

The Engaging Students in Work Placement (ESiWP) working party defines work-integrated learning as: "the integration of academic learning experiences with those in professional practice through workplace experience (including work placement, work experience, practicum, clinical placement, internships etc)

2 T. Groenewald,. Towards a definition of cooperative education, in INTERNATIONAL HANDBOOK FOR COOPERATIVE EDUCATION, Boston: World Association for Cooperative Education, 17-26 (R Coll \& C Eames eds., 2005). 
that secures learning outcomes that are both transferable and applied". ${ }^{3}$

Working from that definition, the Griffith University Work Integrated Learning Management Guide identifies the following five features of effective work experience:

- Meaningful Work;

- Induction;

- Assessment;

- Reflection and debriefing; and

- Monitoring of the quality of outcomes.

Research into work-integrated learning programs has been summarised through literature reviews, attempted definitions and conceptual models in educational literature for many years. ${ }^{4}$ However in this field, where educational practice is so affected by the pragmatic factors of the workplace, even theoretical models appear to be designed to be context specific.

Overarching theory gives educators comfort in designing learning experiences as it ensures our practices are informed by research, however in this field, where theories of learning are only one of the many factors which impact on the success of the learning experience, they are arguably not as helpful. ${ }^{5}$ This is particularly so where the proposed task requires the creation of a new type of work-integrated experience which is intended to operate in the digital environment and not in the physical workplace which was the focus at the time the Boud, Kolb and Biggs models were conceived. The traditional educational context for work integrated learning centred on the provision of technical or manual experience to bring theory to life in fields such as engineering and medical science. In that paradigm students were expected to participate in normal "working" hours and by a physical contribution to the workforce.

In the digital age the very nature of the "workplace" is changing to accommodate workers who may never physically attend the office but may be engaged on a full time basis from a remote location. The technical skills required for these workers are quite different. Manual skills are being replaced by Information Communication Technology (ICT) skills such as electronic mail, messaging services and video conferencing. Synchronous "on the spot" person to person communication is being replaced by asynchronous digital communication which allows people on opposite sides of the globe to work collaboratively on a project despite their different time zones and geographical locations.

3 L. COOPER, J. ORRELL, \& M. BOWDEN, WORKPLACE-LEARNING MANAGEMENT MANUAL., A GUIDE FOR ESTABLISHING AND MANAGING UNIVERSITY WORK-INTEGRATED LEARNING COURSES, Practica, Field Education and Clinical Education, South Australia: Flinders Press (2003).

4 J. DEWEY, EXPERIENCE AND EDUCATION. New York:MacMillan (1938).,

D. KOLB, EXPERIENTIAL LEARNING. Englewood Cliffs,NJ: Prentice Hall (1984).,

D. Boud, Creating a work based curriculum. in D. BOUD E N. SOLOMON (EDS.) SRHE and Open University Press, UK, 45,45 (2001).,
S. Dressler, and A. Keeling, Benefits of cooperative education for students, in INTERNATIONAL HANDBOOK FOR COOPERATIVE EDUCATION, Boston: World Association for Cooperative Education, 217-236 (R Coll Ë C Eames eds., 2005).,

T. Groenewald, Towards a definition of cooperative education, in INTERNATIONAL HANDBOOK FOR COOPERATIVE EDUCATION, Boston: World Association for Cooperative Education, 17-26 (R Coll 8 C Eames eds.,2005).

5 G. Van Gyn, and E. Grove-White, Theories of learning in education, in INTERNATIONAL HANDBOOK FOR COOPERATIVE EDUCATION, Boston: World Association for Cooperative Education 27-36 (R Coll EB C Eames eds. 2005). 


\section{Who are the participants?}

Work-integrated learning programs generally involve at least three parties: the student, the workplace supervisor and an academic coordinator.

From the students' perspective work-integrated learning experiences provide an opportunity for students to augment their theoretical training with practical skills, learn about career options, explore their abilities and mature as they move towards transition to the professional workplace. 6 Where the experiences involve physical placement in a workplace they may also present some drawbacks from the student perspective including transportation costs, additional expense in meeting workplace dress standards and limited opportunities to obtain experience in the student's particular area of interest. ${ }^{7}$

From the employer's perspective the potential benefits of work-integrated learning experiences include the opportunity to: screen potential graduate employees, engage positively with the higher education sector, increase market awareness of the firm culture and take advantage of students' currency of knowledge in the relevant discipline field. The potential drawbacks include difficulties in: managing relationships with students $^{8}$ giving appropriate feedback, ${ }^{9}$ finding physical space for students who are placed in the organisation and the pressure of having to supervise the student in an already busy schedule.

From the university's perspective work-integrated learning opportunities improve the quality of the educational experience for students, offer a recruitment advantage, assist the university in building networks and stimulate curriculum development. International work experience placements also offer universities the opportunity to enhance their international status and develop their international expertise. ${ }^{10}$ The potential drawbacks from the university perspective include: the logistical difficulties often encountered in finding placements, a lack of staff with the necessary practical experience to coordinate the program effectively and the lack of career development opportunities for the academic staff members involved in such programs as distinct from research based opportunities. ${ }^{11}$

\section{The Higher Education Context}

The higher education sector in Australia has undergone a period of rapid change during the last decade. An altered funding model, new levels of competition between providers, an increasing emphasis on research quantity and quality and a larger, more diverse and demanding student population are all factors which affect Australian University strategic plans in the digital age. The strategies currently employed by Australian universities in these changing times are both proactive and reactive in nature. A substantial number of strategies are aimed at improving the quality of the educational experience for the new student body.

6 C. Cates, $\mathcal{E}$ P. Jones, Learning Outcomes and the educational value of cooperative education, (1999), http:// www.waceinc.org.

7 L. BATES, BUILDING A BRIDGE BETWEEN UNIVERSITY AND EMPLOYMENT: WORK INTEGRATED LEARNING. (2005).

8 N. Pepper, Supervision: a positive learning experience or an anxiety provoking exercise?, AUSTRALIAN SOCIAL WORK, 55-64 (1996).

9 M. Eisenberg, K. Heycox Eु L. Hughes, Fear of the personal: Assessing students in practicum, AUSTRALIAN SOCIAL WORK, 33-40 (1996).

10 M. Weisz, $\mathcal{E}$ R. Chapman, Benefits of Cooperative Education for Educational Institutions, in
INTERNATIONAL HANDBOOK FOR COOPERATIVE EDUCATION, Boston: World Association for Cooperative Education 247-258 (R Coll E) C Eames eds., 2005).

11 Martin in J. Orrell, L. Cooper, $\mathcal{E}$ R. Jones, Making the Practicum Visible, HERDSA Conference 1999, 1 (1999) http://www.flinders.edu.au/teach/t4l/practicum/resources/p df/herdsa99.pdf. The Higher Education Research and Development Society of Australasia is a scholarly society for people committed to the improvement of teaching and learning in higher and tertiary education. The HERDSA Annual conference attracts academics from throughout Australasia and acknowledgement of this issue at the annual conference is indicative of its relevance to the Australian Higher Education sector. 


\section{Course Experience Questionnaire (CEQ)}

One useful source of data which Australian universities access in order to gain insight into students' perception of their educational experience is the data collected by the Course Experience Questionnaire (CEQ). This is an instrument which has been used over the past decade to obtain student feedback on the quality of Australian higher education. Every graduate is surveyed a few months after the completion of their studies. An interpretation and analysis of this data was recently undertaken as a major research project titled 'Accessing the Student Voice' and was completed in December 2005. The project was funded by the Federal Department of Education, Science and Training and included an analysis of what 'promotes engagement in productive learning in Australian higher education'.12

One part of the project involved a number of workshops with key university staff held throughout Australia to discuss a range of issues relating to the study of the CEQ data. It is noted that there was general agreement that in the current higher education context, universities faced a dilemma involving 'how best to balance mission (achieving the key purposes of the university) with market (giving students what they want in order to gain and retain them - even if this is specific, skills-focused job training) '. ${ }^{13}$ Participants concluded that managing this dilemma required universities to be continuously aware of rapid changes in both their disciplinary and external environments.

\section{Improving the QUT Student Experience}

Queensland University of Technology (QUT) is conversant with the need to balance mission and market and has utilised its strategic planning process to emphasise the importance of improving the student experience while strengthening 'real world' engagement. One of the University's Learning and Teaching Strategies is to 'Strengthen the real-world focus of learning experiences through developing and strengthening active partnerships and collaborations within and beyond the University'. ${ }^{14}$

The beneficial learning experiences created through work-integrated learning have proven to be a positive factor in improving the student experience with research showing that 'engagement in activities contribut[es] to enhanced academic outcomes'. 15

\section{Community Engagement through Work-integrated Learning}

QUT connections with the community have been strong and enduring. In fact, the current QUT Mission is 'to bring to the community the benefits of teaching, research, technology and service'. ${ }^{16}$ The emphasis on community activities has recently changed from 'community service' to 'community engagement' with a focus upon outcomes which are mutually beneficial for both the University and the community. This trend has been given a national impetus through the work of the Australian Universities Community Engagement Alliance (AUCEA). This organisation is committed to a form of engagement which is clearly two-way by promoting 'direct and mutually beneficial interaction between universities and communities'. 17

12 G. Scott, Accessing the Student Voice: Using CEQuery to identify what retains students and promotes engagement in productive learning in Australian higher education, Final Report of a Project funded by the Department of Education, Science and Training. (2005) http://www.dest.gov.au/ sectors/higher_education/publications_resources/profiles/

$13 \mathrm{Id}$. access_student_voice.htm

14 QUT LEARNING AND TEACHING PLAN 20052009, (2005), http://www.qut.edu.au/about/learnteach.jsp.

15 A. FURCO, Strengthening community engagement in higher education. Seminar held at Queensland University of Technology, Brisbane, October 12, 2005 (2005).

16 QUT MISSION, (2005), http://www.qut.edu.au/about/ university/mission.jsp.

17 AUCEA (Australian Universities Community Engagement Alliance Inc.) (2006), http://www.aucea.net.au/. 
Work-integrated learning clearly falls within this form of community engagement. It has recently been suggested that one measure of the community engagement undertaken by universities should include an assessment of the percentage of students undertaking a domestic or international workplace learning experience. 18

\section{The Law Perspective}

The Faculty of Law at QUT is one of the largest Law Faculties in Australia. In 2005 the Faculty had 2419 students enrolled in its Bachelor of Laws (LLB) and associated double degree courses. Of those, 647 were enrolled as external students.

A diverse range of undergraduate and postgraduate courses are delivered by the Faculty in conjunction with practical legal training programs which enable the requirements for admission to professional legal practice to be satisfied.

The Faculty caters effectively for the diverse learning needs of students through a range of on- and offcampus delivery modes, all of which include components of online delivery which provide a greater level of flexibility in terms of accessing study materials and resources, access to staff and the completion of assessment items. In addition, steps have been taken to ensure that graduates enter the workforce with appropriate levels of theory and knowledge combined with the requisite capabilities and skills required of both law and justice professionals to operate effectively in the context of professional practice.

In its major review of the Federal Civil Justice System ${ }^{19}$ the Australian Law Reform Commission concluded that legal education should be more concerned with "what lawyers need to be able to do " as distinct from the traditional Australian approach which has been centred around "what lawyers need to know". In response to that recommendation and a number of other reports echoing the same theme, the QUT Faculty of Law integrated professional attributes within the content of all substantive undergraduate law units to facilitate incremental capability development throughout the LLB degree.

To ensure incremental development, each specific skill was broken down into three levels to represent gradual attainment. The first level involves scoping of the component parts of the skill, the second level provides an opportunity to practise the component parts of the skill and the third level offers an understanding of the skill in the context of practice. Broadly speaking, those three levels are developed through core units in the first, second and third years of the LLB respectively.

Essential to the project was the pedagogical aim to embed skills training within the content of learning and to specifically assess competency levels within each of the skills through a reflective process that would lead to the development of a "student capability profile". To be effective, this learning approach requires each skill to be developed through a cycle of instruction, practice, feedback and assessment both horizontally and vertically through the LLB degree, and that project was implemented effectively from 2000 to 2003.

Attempts to physically place undergraduate law students into relevant professional workplaces have not however been as successful in the QUT experience and this is due to the large number of students in the undergraduate program and competition from other Law faculties for the limited number of placements available in Brisbane. In addition there is a significant cohort of post-graduate students the Faculty must place through the Graduate Diploma in Legal Practice program. The Law Admissions Consultative

18 S. HARDING, Engagement: Wobbly Third Leg Or Core Approach?, Knowledge Transfer and Engagement Forum, Sydney (2006)

19 ALRC DP 62, August 1999. 
Committee of Queensland requires that every entry level lawyer should have experience in a law office before being admitted. For that reason the Faculty must ensure that each Graduate Diploma in Legal Practice graduate has a placement experience in a law office to satisfy legal practitioner admission requirements.

With an annual student intake of approximately 232 in the QUT Legal Practice course in 2005 and plans for further growth, the Faculty's professional relationships are currently under strain to find geographically convenient placement opportunities for those post-graduate students. As a result, work-integrated learning experiences for undergraduate law students have to date been restricted to specific internship positions (approx 25 per year), voluntary vacation placement opportunities and vacation research experience scholarships for high achieving students. In our current curriculum we are therefore only able to offer approximately $14 \%$ of our undergraduate students a university controlled workplace learning opportunity.

\section{Converging work-based and campus learning through ICT}

New Information and Communication Technologies (ICT) are transforming the practices of both universities and workplaces. The internet, mobile technologies and particularly email have transformed traditional methods of communication within organisations. As the concept of "workplace" expands to accommodate employees who may never physically attend the office but may be engaged on a full time basis from a remote location, the communication methods utilised within such workplaces are also changing. Synchronous person to person communication is being supplemented and in some cases replaced by asynchronous digital communication which allows people on opposite sides of the globe to work collaboratively on a project despite their different time zones and geographical locations.

At the same time ICTs are contributing to a surge of global initiatives in online learning and eLearning in campus-based higher education. Whilst many universities are now using ICT for the flexible delivery of content, there are fewer examples of the effective use of technology to enable student centred and flexible learning which focuses on the learner rather than the transmission of content by the teacher. ${ }^{20}$

Given the transforming nature of workplaces and the radical changes in work practices in organisations which have a sophisticated technological infrastructure, it is submitted that authentic work-integrated learning experiences can and should now be created in the virtual paradigm.

Similarly, given the wealth of current research documenting the changing nature of the way today's students learn and the competing demands on their time, it is submitted that work placement opportunities which enable flexible delivery and flexible learning are also a desirable addition to the traditional physical placement programs offered by universities.

\section{ENGAGING STUDENT LEARNERS}

Engaging student learners - accommodating learning preferences of Generation Y students

In 2004, it was predicted 21 that by 2006 the majority of undergraduate students attending Australian

20 D. Radcliffe, Technological and Pedagogical Convergence between Work-based and Campus-based Learning, EDUCATIONAL TECHNOLOGY AND SOCIETY 5(2) (2002).
21 D. Jonas-Dwyer $\mathcal{E}$ R. Pospisil, The Millennial Effect: Implications for Academic Development, (2004), http://herdsa2004.curtin.edu.my/Contributions/Refereed Papers.htm. 
universities would belong to Generation Y;22 that is, born after 1980: and also known as Millennials, echo boomers digital natives or the net generation. Generation $\mathrm{Y}$ are the first generation of students to have grown up with digital media and information technology in a developed, prolific form. ${ }^{23}$ Technology forms such a key part of who they are that, for Generation Y students, computers and the Internet are regarded as simply part of the environment and not as "technology"; this term is reserved only for the most recent "gadgets". 24 The variety and level of Generation Y's exposure to information technology media during their formative years has led to a shift in learning preferences as compared with past student generations. ${ }^{25}$

Although other factors, in addition to theories of learning, will impact on the success of work integrated learning programs, 26 it remains appropriate to consider the learning preferences of the majority of participating students when developing the virtual work placement model. Research shows that as student attitudes and aptitudes change, so too do their learning preferences, and suggests that in order to ensure a more effective learning environment, learning and teaching strategies must adapt to meet these preferences. 27 By taking into account what today's students value most, it is hoped that we can more effectively engage them, with a view to positively influencing their learning experience, understanding and learning outcomes.

Oblinger ${ }^{28}$ identifies technology use, experimental activities, structure and teamwork, as the learning styles preferred by Generation Y. The significance of these learning styles to the design of a virtual work integrated learning model is considered below.

22 Generation $Y$ are also known as Millennials, Echo Boomers, Digital Natives and the Net Generation. See further C. Raines, Managing Millennials, (2002), http://www.generationsatwork.com/articles/ millenials.htm; M. Prensky, Digital Natives, Digital Immigrants, (2001), http://www.marcprensky.com/ Writing/default.asp, D. Tapscott, GROWING UP DIGITAL: THE RISE OF THE NET GENERATION. New York, NY: McGrawHill (1998).

23 C. Raines, Managing Millennials, (2002), http://www.generationsatwork.com/articles/millenials.htm .

24 J.L. Frand, The Information Age Mindset: Changes in Students and Implications for Higher Education. EDUCAUSE REVIEW, 35(5), 15-24 (2000); D. Oblinger, Boomers Gen-Xers Millennials, Understanding the New Students. EDUCAUSE REVIEW, 38(4), 37-47 (2003).

25 M. McCrindle, Understanding Generation Y., PRINCIPAL MATTERS, 28-31 (2003); D. Oblinger, E⿱ J. Oblinger, Is It Age or IT: First Steps Toward Understanding the Net Generation, in EDUCATING THE NET GENERATION, 2.1-2.20. (D.G. Oblinger $\mathcal{E}$ J.L. Oblinger eds. 2005), http://www.educause.edu/ content.asp?page_id $=5989 \mathcal{E} b \operatorname{ch} p=1 ; D$. Oblinger, Boomers Gen-Xers Millennials, Understanding the New Students, EDUCAUSE REVIEW, 38(4), 37-47 (2003); J.L. Frand, The Information Age Mindset: Changes in Students and Implications for Higher Education.
EDUCAUSE REVIEW, 35(5), 15-24 (2000); P. Mellow, The Media Generation: Maximise Learning by Getting Mobile, (2005), http://www.ascilite.org.au/conferences/ brisbane05/blogs/proceedings/53_Mellow.pdf.

26 G. Van Gyn, and E. Grove-White, Theories of learning in education, in INTERNATIONAL HANDBOOK FOR COOPERATIVE EDUCATION, 27-36, Boston: World Association for Cooperative Education, (R Coll $\mathcal{E} \mathrm{C}$ Eames eds. 2005).

27 B. Costello, R. Lenholt, E J J. Stryker, Using Blackboard in Library Instruction: Addressing the Learning Styles of Generations $X$ and Y., THE JOURNAL OF ACADEMIC LIBRARIANSHIP, 30(6), $452-460$ (2004); D. Jonas-Dwyer, 83 R. Pospisil, The Millennial Effect: Implications for Academic Development, (2004) http://herdsa2004.curtin.edu.my/Contributions/Refereed Papers.htm ; J.L. Frand, The Information Age Mindset: Changes in Students and Implications for Higher Education, EDUCAUSE REVIEW, 35(5), 15-24 (2000); D. Oblinger, Eु J. Oblinger, Is It Age or IT: First Steps Toward Understanding the Net Generation, in EDUCATING THE NET GENERATION, 2.1-2.20 (D.G. Oblinger Eु J.L. Oblinger eds. 2005), http://www.educause.edu/content.asp?page id $=5989$ Ebc $h p=1$.

28 D. Oblinger, Boomers Gen-Xers Millennials, Understanding the New Students, EDUCAUSE REVIEW, 38(4), 37-47 (2003). 


\section{Technology}

Generation Y students are technology savvy and therefore relate to and appreciate the flexibility and convenience of an online learning and teaching environment. Like all students, they engage better with materials anchored within their own experience and possess a greater potential for deeper learning and understanding when allowed to study on their own terms as to time, place and pace. ${ }^{29}$ Raised in a world of fast food and Internet banking, they have 'zero tolerance for delays' 30 and expect information and resources to be available when and where needed. This desire for convenience or flexibility is enhanced by the fact that many students of this generation balance their study and social life with part or full time work. ${ }^{31}$ The virtual work placement model as an alternative to physical placements will provide students with flexibility in the context of a learning experience which may more effectively engage today's students who are used to the constant connectivity provided by digital media, such as the Internet and online interactive gaming. ${ }^{32}$ Such an approach to communication will also be aligned with what actually occurs in the workplace and will therefore be authentic. Indeed Poole and Zhang 33 claim that 'once people become accustomed to working in virtual contexts - as they rapidly are' - the ability to work in virtual teams will become a 'taken for granted skill.'

However, as more technology is not necessarily better, the model developed will endeavour to focus on the activity enabled by the technology, rather than the mere use of technology per se, so that the virtual learning model will be engaging - by making it more interactive, social or student-centred ${ }^{34}$ - rather than simply focusing on content delivery of knowledge or the packaging of lectures and structured readings online. ${ }^{35}$

\section{Experimental Activities}

Kinaesthetic and visual learning styles are most prevalent in Generation Y learners ${ }^{36}$ - these students learn best through multi-sensory media such as diagrams, graphics, video and flow charts, rather than text. For Generation Y, life is an interactive, rather than passive, experience - they are achievement driven and 'creative, communicative participants rather than ... passive, reception-only consumers'. ${ }^{37}$

29 M. Le Brun, $\mathcal{B}$ R. Johnstone, THE QUIET REVOLUTION, Sydney: Law Book Company (1994).

30 J.L. Frand, The Information Age Mindset: Changes in Students and Implications for Higher Education, EDUCAUSE REVIEW, 35(5), 15-24 (2000).

31 K.Manuel, Teaching Information Literacy to Generation Y, JOURNAL OF LIBRARY ADMINISTRATION, 36(12), 195-217 (2002); C. Raines, Managing Millennials, (2002), http://www.generationsatwork.com/articles/ millenials.htm .

32 D. Oblinger, Boomers Gen-Xers Millennials, Understanding the New Students, EDUCAUSE REVIEW, 38(4), 37-47 (2003).

33 M.S. Poole 8 H. Zhang, Virtual Teams, in THE HANDBOOK OF GROUP RESEARCH AND PRACTICE, 363-384, Thousand Oaks: Sage Publications, (S. Wheelan Ed., 2005).

34 D. Oblinger, Eु J. Oblinger, Is It Age or IT: First Steps Toward Understanding the Net Generation, in EDUCATING THE NET GENERATION, 2.1-2.20 (D.G. Oblinger $\mathcal{E}$ J.L. Oblinger eds. 2005), http://www. educause.edu/content.asp?page $i d=5989 E$ Ebchp $=1$; J.L. Frand, The Information Age Mindset: Changes in Students and Implications for Higher Education, EDUCAUSE REVIEW, 35(5) 15-24 (2000); D. Laurillard, Multimedia and the Changing Experience of the Learner, BRITISH JOURNAL OF EDUCATIONAL TECHNOLOGY, 26(3) 179-189 (1995); D. Radcliffe, Technological and Pedagogical Convergence between Work-based and Campus-based Learning, EDUCATIONAL TECHNOLOGY AND SOCIETY, 5(2) (2002).

35 B.L. McCombs \&ु D. Vakili, A Learner-Centered Framework for E-Learning, TEACHERS COLLEGE RECORD, 107(8) 1582-1600 (2005).

36 D. Oblinger, $\mathcal{B} \mathrm{J}$. Oblinger, Is It Age or IT: First Steps Toward Understanding the Net Generation, in EDUCATING THE NET GENERATION, 2.1-2.20 (2005), $\quad$ http://www.educause.edu/content. asp?page_id $=5989$ Gbchp=1 ; K. Manuel, Teaching Information Literacy to Generation Y, JOURNAL OF LIBRARY ADMINISTRATION. 36(1-2) 195-217 (2002); J.L. Frand, The Information Age Mindset: Changes in Students and Implications for Higher Education, EDUCAUSE REVIEW, 35(5) 15-24 (2000).

37 B. Alexander, Going Nomadic: Mobile Learning in Higher Education, EDUCAUSE REVIEW, 39(5) 29-35 (2004). 
As today's students prefer "active learning" or learning experiences which actively engage them within the learning process and encourage them to construct their own learning by "doing" rather than simply being told, the interactive discovery approach to learning which will be implemented in the virtual model will, it is anticipated, decrease boredom, whilst increasing student participation and retention of skills and knowledge. ${ }^{38}$ Studies have shown that students retain five percent of materials presented in lectures, ten percent of what they read, 20-30 percent of what they see, and 75 percent of what they do. However, as it has been recognised that a balance needs to be maintained between didactic and discovery (process over content), approaches, ${ }^{39}$ the model developed will also enable opportunities for academic and workplace instructors to moderate and guide the learning process in more traditional ways.

\section{Structure}

Generation Y students value structure and feedback 40 and expect learning to be "high touch" as well as "high tech". ${ }^{41}$ Although they are accustomed to multitasking and quickly switching from one activity to another with minimal adjustment time, Generation $Y$ students have a short attention span and a preference for processing information in "bite sized chunks" or a concise easy to use format. ${ }^{42}$ They therefore prefer a step by step approach to learning, which assists to make information more manageable and readily processed. 43 The virtual model developed will enable students to work through authentic tasks in a structured way in a supportive learning environment which appropriately scaffolds or structures the learning and teaching process. As suggested by Frand, 44 "the instructor needs to play a more Socratic role, posing questions and guiding the learning process, rather than taking an ecclesiastical approach, providing "the word" on a subject that the student is to "learn" (memorize) and repeat back." Therefore, although tasks may be carried out online, feedback, and monitoring by instructors, still fulfils an important motivational role. ${ }^{45}$ It is anticipated that this support and structure will feature in the virtual work placement model, by an appropriate mix of synchronous and asynchronous online communication such as video, skype, ${ }^{46}$ online discussion and email, and some opportunities for face to face communication.

38 M. Garry, Training for the Nintendo Generation, PROGRESSIVE GROCER 87 75(4) (1996); D. Oblinger, $\mathcal{E}$ J. Oblinger, Is It Age or IT: First Steps Toward Understanding the Net Generation, in EDUCATING THE NET GENERATION. 2.1-2.20 (D.G. Oblinger 89 J.L. Oblinger eds. 2005) http://www.educause.edu/content.asp?page_id $=5989$ Ebc $h p=1$

39 J.L. Frand, The Information Age Mindset: Changes in Students and Implications for Higher Education, EDUCAUSE REVIEW, 18 35(5) (2000).

40 K. Phalen, Self-Assured, Stressed, and Straight: Millennial students and how they got that way, (2002), http://www.itc.virginia.edu/virginia.edu/fall02/student/hom e.html; C. Raines, Managing Millennials, (2002), http://www.generationsatwork.com/articles/millenials.htm.

41 M. Garry, Training for the Nintendo Generation, PROGRESSIVE GROCER 87 75(4) (1996).

42 M. Prensky, Digital Natives, Digital Immigrants, Part II, (2001). http://www.marcprensky.com/writing/default.asp ; P. Mellow, The Media Generation: Maximise Learning by
Getting Mobile, (2005), http://www.ascilite.org.au/ conferences/brisbane05/blogs/proceedings/53 _Mellow.pdf .

43 M. LE BRUN, $\mathcal{E}$ R. JOHNSTONE, THE QUIET REVOLUTION, Sydney: Law Book Company (1994).

44 J.L. Frand, The Information Age Mindset: Changes in Students and Implications for Higher Education, EDUCAUSE REVIEW, 35(5) 15-24 (2000).

45 B. Costello, R. Lenholt, Eु J. Stryker, Using Blackboard in Library Instruction: Addressing the Learning Styles of Generations $X$ and $Y$, THE JOURNAL OF ACADEMIC LIBRARIANSHIP, 30(6) 452-460 (2004); D. Oblinger Eु J. Oblinger, Is It Age or IT: First Steps Toward Understanding the Net Generation, in EDUCATING THE NET GENERATION, 2.1-2.20 (D.G. Oblinger \&ु J.L. Oblinger eds. 2005), http://www.educause.edu/content.asp?page_id $=5989$ Ebc $h p=1$.

46 An online communications system that provides free voice and video conferencing, and synchronous chat or discussion forum functions to other skype users. See http://www.skype.com/download/. 


\section{Teamwork}

Friendship and social relationships assume particular importance for Generation Y. Indeed, their level of socialisation is such that they are almost constantly connected, either in person or online, for example by computers (email, blogs, 47 and synchronous or asynchronous discussion forums), PDAs 48 or mobile phones. ${ }^{49}$ They seek a sense of community - to be included - and are more likely to make decisions based on the collective experience of their peers, rather than their teachers. ${ }^{50}$ As a result, in addition to web-based resources, today's students also desire social interaction and connection, either in person, via mobile technology or online ${ }^{51}$ and gravitate towards activities that promote peer or social interaction and collaborative learning, such as gaming activities. 52

The benefits of such learning and teaching approaches have been widely recognised. ${ }^{53}$ Collaborative activities are appropriate to the Generation Y psyche as they have been found to improve student relationships, social skills and psychological development. In addition, such approaches also increase academic learning and retention; cognitive development; and active engagement, through discussion in which conflicting perceptions of the issue under consideration arise that, due to attempts to reconcile them, are then critiqued, resolved and reformulated by exposing and modifying inadequate reasoning and constructing new knowledge. ${ }^{54}$ Furthermore, given that 'the half-life of information is [now] measured in months and years' 55 the teamwork, communication and leadership skills developed through collaborative

47 A user-generated web site that combines text, images and links to other sites to provide commentary on a topic. "The ability for [users] to leave comments in an interactive format is an important part of many blogs': Blog, (2007), Wikipedia, http://en.wikipedia.org/wiki/Blog .

48 Meaning a "Personal Digital Assistant" or handheld device combining features such as: computing, telephone, facsimile and Internet and networking access.

49 M. McCrindle, Understanding Generation Y, PRINCIPAL MATTERS, 28-31 (2003); J.L. Frand, The Information Age Mindset: Changes in Students and Implications for Higher Education. EDUCAUSE REVIEW, 35(5) 15-24 (2000); D. Oblinger, Eु J. Oblinger, Is It Age or IT: First Steps Toward Understanding the Net Generation, in EDUCATING THE NET GENERATION. 2.1-2.20 (D.G. Oblinger E⿱ J.L. Oblinger eds., 2005).

50 A.Taylor, Do We Know Who We Are Teaching? Teacher Education Undergraduates' Views of the World' (Paper presented at the New Zealand/Australian Association for Research in Education Conference - Educational Research, Risks and Dilemmas, Auckland, 29 November 2003); M. McCrindle, Understanding Generation Y, PRINCIPAL MATTERS, 28-31 (2003); K. Manuel, Teaching Information Literacy to Generation Y, JOURNAL OF LIBRARY ADMINISTRATION, 36(1-2) 195-217 (2002).

51 D. Oblinger, Eु J. Oblinger, Is It Age or IT: First Steps Toward Understanding the Net Generation, in EDUCATING THE NET GENERATION, 2.1-2.20 (D.G. Oblinger Eु J.L. Oblinger eds. 2005), http://www.educause.edu/content.asp?page id $=5989$ Ebc $h p=1$.

52 P. Shield, B. Atweh, EF P. Singh, Utilising Synchronous
Web-mediated Communications as a Booster to Sense of Community in a Hybrid On-campus/Off-campus Teaching and Learning Environment, (2005) http://www.ascilite.org.au/conferences/brisbane05/blogs/pro ceedings/70_Shield.pdf; K. Squire, Eु H. Jenkins, Harnessing the Power of Games in Education, (2003), http://www.iaete.org/insight/articles.cfm? $\mathcal{E} i d=26$.

53 D. Johnson, $\mathcal{B}$ R. Johnson, Learning Groups in THE HANDBOOK OF GROUP RESEARCH AND PRACTICE, 441-461 Thousand Oaks: Sage Publications, (S. Wheelan ed. 2005); D.W. Johnson, Eु R.T. Johnson, Making Cooperative Learning Work, THEORY INTO PRACTICE, 38(2) 67-73 (1999); D.W. Johnson, $\mathcal{E}$ R.T. Johnson, What Makes Cooperative Learning Work, in JALT APPLIED MATERIALS: COOPERATIVE LEARNING. 26-36, Tokyo: Japan Association for Language Teaching, (D. Kluge, S. McGuire, D. Johnson EF R. Johnson eds. 1999); M. LE BRUN, \&ु R. JOHNSTONE, THE QUIET REVOLUTION, Sydney: Law Book Company (1994); E. WENGER, COMMUNITIES OF PRACTICE: LEARNING, MEANING AND IDENTITY, Cambridge, UK: Cambridge University Press (1998); E. Wenger, COMMUNITIES OF PRACTICE: LEARNING AS A SOCIAL SYSTEM, (1998), http://www.ewenger.com/pub/index.htm .

54 D. Johnson, Eु R. Johnson, Learning Groups, in THE HANDBOOK OF GROUP RESEARCH AND PRACTICE, 441-461 Thousand Oaks: Sage Publications (S. Wheelan ed. 2005).

55 J.L. Frand, The Information Age Mindset: Changes in Students and Implications for Higher Education, EDUCAUSE REVIEW, 35(5) 15-24 (2000). 
learning, even when conducted online, are especially important in the context of learning for workplace transition, as opposed to mere knowledge accumulation, thus providing an authentic learning experience which develops marketable life long skills. ${ }^{56}$ An important feature of the virtual placement model is that it will provide students with another opportunity to develop these important skills.

\section{THE VIRTUAL PLACEMENT PROJECT}

\section{The Concept}

The Virtual Placement Project is being designed in accordance with the Flinders University WorkplaceLearning Management Manual57 but accepting Martin's proposition that 'there is no single model of successful practice' 58 and work based university education programs have to be designed to meet the resources and needs of participants.

The target skills for the project are derived from the Teaching for Learning Practicum of the Flinders program and include:

1.Self awareness:- knowledge of personal values, strengths and limitations in the workplace context;

2.Motivation:- knowledge about the employer, ability to prepare a CV and ability to effectively communicate with their supervisor; ${ }^{58}$

3.Intentionality:- the ability for students to establish what they are interested in learning and to consider how the experience will inform their job and future career;

4.Adaptability:- flexibility and the ability to deal with uncertainty; and

5.Capacity to work with others:- awareness of status and roles, the ability to self-manage and respect for others' perceptions.

The aim of the project is to provide an authentic and sustainable virtual workplace experience for undergraduate law students at QUT.

The Virtual Placement Project is intended for offer to full-time, part-time and external QUT students as an elective subject in the Bachelor of Laws program. It is yet to be determined which pre-requisites will apply but it is anticipated that students will participate in the program in their final year of study.

The virtual workplace will operate from the Blackboard Learning Management System supplemented by the QUT ePortfolio program. ${ }^{60}$ It is also anticipated that once students are allocated to a placement, they

56 D. Hanna, Building A Leadership Vision: Eleven Strategic Challenges for Higher Education 38(4), EDUCAUSE REVIEW 25 (2003).

57 L. COOPER, J. ORRELL, \& M. BOWDEN, WORKPLACE-LEARNING MANAGEMENT MANUAL, A GUIDE FOR ESTABLISHING AND MANAGING UNIVERSITY WORK-INTEGRATED LEARNING COURSES, Practica, Field education and Clinical Education, South Australia: Flinders Press (2003).

58 E. MARTIN, THE EFFECTIVENESS OF DIFFERENT MODELS OF WORK-BASED UNIVERSITY EDUCATION, Department of
Employment, Education, Training and Youth Affairs, J.S McMillan Printing Group (1997).

59 This task is included to enhance students' readiness for the transition to professional practice.

60 The QUT Student Portfolio and Resumé Builder services are available to all students through the QUT Virtual network. Student Portfolio is an online tool that students can use to document and present their academic, professional and personal development in the format of an e-portfolio (electronic portfolio). The e-portfolio enables students to facilitate the electronic development and management of a digital career 'folio' of evidence. 
will be given a level of access to the technological infrastructure used by their virtual employers. It is hoped that the technological platform will provide an appropriate mix of synchronous (real time) and asynchronous online communication such as video, skype, ${ }^{61}$ discussion forum, online chat, wikis ${ }^{62}$ and email as well as some opportunities for face to face communication.

\section{The Aspirations}

As this project is still in the developmental phase our learning design goals are aspirational. From our research to date we envisage a program with the following main features.

Students will apply for their work placement position by answering an advertisement in the virtual workplace newspaper. It is anticipated that the range of available placement opportunities will give students the opportunity to choose an experience in their preferred field. Specific criteria will apply and students will need to prepare a resumé outlining their experiences and demonstrated strengths and interests. Student resumés will need to be prepared using the QUT Student Portfolio and Resumé Builder services which are available to all students through the QUT Virtual network. Student Portfolio is an online tool that students can use to document and present their academic, professional and personal development in the format of an e-portfolio (electronic portfolio). The format of the service encourages students to identify their strengths and areas for improvement, also providing resources designed to help them to undertake an audit of how their skills development is progressing, and to plan for future skills development. The Resumé Builder is provided by QUT to enable students to prepare themselves to address employment opportunities as they arise.

This service enables students to:

1. record the details they may wish to include in their resumé;

2. create a resumé using a selection of those recorded details; and

3. export that resumé electronically as a file which can be opened for further editing or viewing in another application.

In preparing their applications students will be referred to the websites of their employers to explore the public profile and market niche of the organisation.

In response to their applications, students will receive virtual letters of acceptance which will allocate them to workteams and employers on the basis of their expressed preferences. It is anticipated that the range of employers will extend across the spectrum of law firms, government, industry and community organisations, reflecting the wide variety of employment opportunities which are open to today's law graduates. It is envisaged that at this point students will also be invited to participate in their employer's virtual workplace, being granted a level of access to the organisation's intranet, online research tools, group emails and continuing education and professional development services. ${ }^{63}$ Throughout this period students will also be encouraged to develop team familiarity through an assessed interactive online exercise conducted by the

61 The Skype communications system is notable for its broad range of features, including free voice and video conferencing, its ability to use peer to peer (decentralized) technology to overcome common firewall.

62 A wiki is a website that allows visitors to easily add, remove, and edit available content, typically without the need for registration. This ease of interaction and operation makes a wiki an effective tool for mass collaborative authoring.

63 It is acknowledged that this raises issues such as confidentiality and site security which may need to be addressed on a case by case basis in accordance with both University and Employer organisational policies. 
University on the learning management system (LMS) platform. ${ }^{64}$

After teams have been allocated to employers, tasks will be set by workplace mentors in each employer organisation. Students will be asked to collaborate to prepare a plan of action to scope their approach to completing the task including an allocation of workloads and a timeline for completion. This plan of action will also require students to identify aspects of the task which may require expert advice from other sources or resources not ordinarily available.

Following submission of the group's plan of action, workplace mentors will provide feedback to the group highlighting practical considerations that may have been overlooked as well as the ethical, political and social dimensions of the task that may not have been readily apparent to the students in their initial proposal.

The major assessment item will then involve completion of the assigned task in groups. It is envisaged that given the range of employers, the nature of these tasks may include diverse activities such as research into legal problems, the preparation of client briefings on updates to the law in specific areas, memoranda of advice in relation to legal issues and submissions on issues of law reform or public policy. It is anticipated that the scope of the task may need to be modified along the way to reflect client's needs and the impact of other "real world" factors. The timing of submission of the task will therefore be negotiable between the students and the workplace mentor.

The workplace mentors will assess the project and give detailed feedback to the group on the strengths, weaknesses and practical utility of the work produced. Wherever possible it is proposed that students will receive a "red pen" or corrected version of the task which they will be asked to revise in accordance with their mentor's input. It is also hoped that wherever possible students will ultimately see their work implemented in the "real world" context and receive feedback from their mentor regarding their client's satisfaction with the work produced and where relevant, the outcome of the matter.

The final stage of the project will involve students being asked to revisit their original resumés through the ePortfolio service to record and reflect upon their workplace experience and how they feel it has contributed to their preparation for transition to professional practice. 65

\section{CONCLUSION}

Work-integrated learning experiences are intended to supplement the traditional didactic approaches to teaching experienced by students elsewhere in their studies of "black letter" law.

The creation of an effective work-integrated learning experience which is intended to operate in the digital environment and not in the physical workplace requires significant adaptation of the traditional learning theories which have underpinned educational literature in this field to date. However, the current policy imperatives of the higher education sector in Australia, the practical challenges encountered in attempting to implement the traditional models in modern universities and the rapidly changing nature of today's students' learning preferences suggest that it is a worthwhile goal.

The Virtual Placement Project currently under design in the Faculty of Law at the Queensland University of Technology is a working example of an attempt to reconcile these various factors in the design of an authentic and rewarding learning experience for law students preparing for the "real world" of professional practice.

64 A Learning Management System (or LMS) is a software package that enables the management and delivery of online content to learners. Most LMSs are web-based to facilitate "anytime, any place, any pace" access to learning content and administration. The assessed interactive activity is likely to be an online quiz competition.
65 The task of reflection is intended to consolidate in the students' minds the value of the learning experience so that they can supplement their CVs for future use as a result of the placement experience. It is not yet determined whether the assessment will be decided on a graded or competency basis. 